\title{
Pengaruh Latihan Gerak Aktif Kaki dengan Teknik Open Kinetic Chain Exercise terhadap Penurunan Intensitas Nyeri pada Lansia dengan Nyeri Sendi Osteoartritis dan Rheumatoid
}

\author{
Asminarsih Zainal Prio ${ }^{1^{*}}$, Sitti Rachmi Misbah ${ }^{2}$, Fitri Wijayati $^{3}$ \\ ${ }^{1}$ Jurusan Keperawatan, Poltekkes Kemenkes Kendari, Indonesia: asminarsih0408@gmail.com \\ ${ }^{2}$ Jurusan Keperawatan, Poltekkes Kemenkes Kendari, Indonesia \\ ${ }^{3}$ Jurusan Keperawatan, Poltekkes Kemenkes Kendari, Indonesia \\ *(Korespondensi e-mail: asminarsih0408@gmail.com)
}

\begin{abstract}
ABSTRAK
Tidak ada latihan khusus untuk orang tua dengan rasa sakit yang disebabkan oleh Osteoarthritis dan rheumatoid di lembaga sosial Minaula Lansia di Kendari. Penelitian ini bertujuan untuk memeriksa efek dari latihan kaki dengan metode rantai kinetik terbuka pada penurunan rasa sakit pada orang tua dengan rasa sakit yang disebabkan oleh Osteoarthritis dan rheumatoid. Metode yang digunakan dalam penelitian ini adalah quasi eksperimental menggunakan Pretest dan posttest dengan desain kelompok kontrol. Pengumpulan data dilakukan dengan pengambilan sampel acak sederhana untuk mencapai 60 peserta 930 dalam kelompok intervensi dan 30 dalam kelompok kontrol). Hasilnya menunjukkan bahwa berarti tingkat nyeri kelompok intervensi menurun sebagai 4, 83 setelah latihan kaki dengan metode rantai kinetik terbuka (berarti sebelum 5, 80, berarti setelah 0,97). Kesimpulan dari penelitian ini ada efektivitas latihan kaki dengan metode rantai kinetik terbuka untuk menurunkan tingkat rasa sakit pada orang tua dengan rasa sakit yang disebabkan oleh Osteoarthritis dan rheumatoid di Minaula lembaga sosial Lansia di Kendari 2016 (nilai $\mathrm{p}=0000$ ). Penelitian ini menyiratkan bahwa latihan kaki dengan metode rantai kinetik terbuka dapat dipertimbangkan sebagai salah satu kompetensi Keperawatan dan diterapkan sebagai intervensi keperawatan untuk penurunan tingkat nyeri yang disebabkan oleh Osteoarthritis dan rheumatoid.
\end{abstract}

Kata kunci: Gerakan kaki, Lansia, Metode open kinetic chain, Osteoartritis

Abstract

There was not specialy exercise for elderly with pain caused by osteoarthritis and rheumatoid at the Minaula Social Institution of Elderly at Kendari. This researches aims to examine the effect of foot exercise with open kinetic chain methods on decreasing pain on elderly with pain caused by osteoarthritis and rheumatoid at the Minaula Social Institution of Elderly at Kendari. The method used in this research was quasi experimental using pretest and posttest with control group design. Data collections was conducted by simple random sampling to reach 60 participant 930 in intervention group and 30 in control group). The result showed that mean of pain level of intervention group was decreased as 4,83 after foot exercise with open kinetic chain methods (mean before 5,80, mean after 0,97 ). The conclution of this research there was an effectiveness of foot exercise with open kinetic chain methods to decreased pain level in elderly with pain caused by osteoarthritis and rheumatoid at Minaula Social Institution of Elderly at Kendari 2016 ( $\mathrm{p}$ value $=0,000$ ). This research implied that foot exercise with open kinetic chain methods can be consider as one of nursing competencies and applied as a nursing intervention to decreased pain level caused by osteoarthritis and rheumatoid.

Keywords: Elderly, Foot exercise, Osteoartrithis, Open kinetic chain methods, Pain 


\section{PENDAHULUAN}

Menurut Undang Undang Kesehatan Republik Indonesia nomor 36 tahun 2009 tentang kesehatan lanjut usia adalah seseorang yang telah mencapai usia 60 tahun ke atas. Indonesia sendiri menduduki rangking keempat di dunia dengan jumlah lansia 24 juta jiwa yang belum terlalu mendapat perhatian. Tidak hanya menghadapi angka kelahiran yang semakin meningkat, Indonesia juga menghadapi beban ganda (double burden) dengan kenaikan jumlah penduduk lanjut usia (60 tahun ke atas) karena usia harapan hidup yang makin panjang bisa mencapai 77 tahun (Depkes RI, 2010).

Laporan jumlah lanjut usia di Sulawesi tenggara pada tahun 2011 yang berusia berusia 60 tahun keatas sebesar 132.810 jiwa dan lanjut usia pada tahun 2012 yang berusia berusia 60 tahun keatas sebesar 134.965 Jiwa dan lanjut usia pada tahun 2013 yang berusia berusia 60 tahun ke atas sebesar 137.130 Jiwa.

Pertambahan jumlah penduduk lanjut usia akan diikuti pula oleh meningkat dan kompleksnya permasalahan yang dihadapi para lansia. Secara individu, pengaruh proses menua dapat menimbulkan berbagai masalah baik fisik, biologis, mental maupun sosial ekonomis. Salah satu penyakit yang sering di alami oleh lansia adalah nyeri Osteoatritis (Nugroho, 2008).

Osteoarthritis adalah salah satu kelainan muskuloskeletal yang paling sering dijumpai di seluruh dunia dan merupakan penyebab utama impairment dan disabilitas. Osteoartritis merupakan suatu keadaan patologi yang mengenai kartilago hialin dari sendi lutut, di mana terjadi pembentukan osteofit pada tulang rawan sendi dan jaringan subchondral yang menyebabkan penurunan elastisitas dari sendi. Jika kerusakan berlangsung terus berlanjut maka, bentuk sendi tidak beraturan dengan adanya penyempitan celah sendi, osteofit, ketidakstabilan dan deformitas.
Dengan terbentuknya osteofit maka akan mengiritasi membran sinovial dimana terdapat banyak reseptor-reseptor nyeri dan kemudian akan menimbulkan hidrops. Dengan terjepitnya ujung-ujung saraf polimodal yang terdapat di sekitar sendi karena terbentuknya osteofit serta adanya pembengkakan dan penebalan jaringan lunak di sekitar sendi maka akan menimbulkan nyeri tekan dan nyeri gerak.

Penatalaksanaan untuk osteoatritis diantaranya adalah dengan menggunakan obat, istrahat, relaksasi, olahraga, diet, intruksi tentang penggunaan sendi yang baik, dan cara menghemat energy tubuh. Aktivitas gerak fisik atau olahraga dapat mengurangi nyeri dan kekakuan sendi, serta dapat meningkatkan kelenturan, otot yang kuat dan ketahanan.

Latihan gerak aktif merupakan serangkaian gerak fisik yang dilakukan dalam usaha penyembuhan atau meningkatkan kualitas hidup penderita, mengelola penyakitnya dan menunda atau meniadakan komplikasi yang akan ditimbulkannya. Penggunaan aktivitas fisik sebagai usaha terapi tidak dapat berdiri sendiri, melainkan bersifat komplementer dengan usaha terapi yang lain misalnya pengaturan makan dan pengobatan konvensional yang telah terbukti peranannya (Herry, 2009).

Dengan pemberian latihan aktif bertujuan untuk meningkatkan stabilitas sendi dan kekuatan otot-otot sekitar lutut terutama Quadriceps terutama pada $\mathrm{m}$. vastus medialis karena latihan ini berguna untuk mengurangi iritasi yang terjadi pada permukaan kartilago artikularis patella, memelihara dan meningkatkan stabilitas aktif pada sendi lutut juga dapat memelihara nutrisi pada synovial menjadi lebih baik. Dengan gerakan yang berulang pada latihan ini akan terjadi peningkatan kerja otot-otot sekitar sendi sehingga mempercepat aliran darah sehingga metabolisme juga ikut meningkat sehingga sisa-sisa metabolisme akan ikut terbawa aliran darah sehingga nyeri berkurang. 
Berbagai penelitian telah dilakukan terkait efektifitas latihan isotonik Open kinetic chain Exercise terhadap penurunan nyeri yaitu oleh fehr G.L; Junior A.C; Cacho E.W.A; dan Miranda J.B (2006); Kachanathu S.J; Kaur H; Natho M; dan Nuhmani S (2013). Serta pengaruh Open Kinetik Chain Exercise terhadap peningkatan aktivitas fungsional oleh Nugroho H.B. (2015).

Data Jumlah Lansia di Panti Sosial Trena Werdha Minaula Kendari adalah 95 orang pada tahun 2015, dengan jumlah Lansia penderita Osteoartritis 33 orang. Latihan fisik yang dilaksanakan di Panti Sosial Tresna werdha Minaula Kendari adalah berupa senam Lansia yang dilakukan pada seluruh tubuh. Lansia osteoarthritis yang tinggal di Panti Sosial tresna werdha Minaula Kendari sering kali tidak mengikuti senam lansia tersebut dengan alasan merasakan nyeri pada lutut dan pergelangan kaki, merasakan kelelahan, dan kadang merasa nyeri kambuh bila mengikuti semua gerakan senam yang diajarkan. Berdasarkan fenomena tersebut maka peneliti tertarik untuk menciptakan produk latihan gerak aktif kaki isotonic dengan teknik open kinetic chan exercise khusus pada penderita osteoarthritis untuk menurunkan nyeri sendi lansia.

Berdasarkan uraian di atas maka peneliti akan melakukan penelitian tentang Pengembangan Model Latihan Gerak Aktif Kaki Isotonik Dengan Teknik Open Kinetik chain Exercise Untuk Menurunkan Intensitas Nyeri dan kekakuan, serta Peningkatan Aktivitas fungsional Pada Usia Lanjut Penderita Osteoartritis Di Panti Sosial Tresna Werdha Minaula Kendari Tahun 2016.

Tujuan penelitian ini adalah untuk mengembangan model latihan gerak aktif kaki dengan teknik open kinetic chain exercise dan pengaruhnya terhadap intensitas nyeri Pada Usia Lanjut Penderita nyeri sendi Di Panti Sosial Tresna Werdha Minaula Kendari tahun 2016.

\section{METODE}

\section{Jenis Penelitian}

Penelitian ini akan mengembangkan Model Latihan Gerak Aktif Kaki yang Khusus digunakan pada usia lanjut penderita Osteoartritis. Penelitian ini menggunakan strategi penelitian dan pengembangan atau research \& development ( $R \& D)$.

Alasan mengapa dipilih strategi penelitian dan pengembangan adalah strategi ini merupakan strategi yang sangat powerfull untuk mengembangkan praktek dengan menghasilkan produk pengembangan. Selain itu penggunaan pendekatan penelitian dan pengembangan tujuannya bukan hanya menemukan profil impelementasi atau praktek, namun lebih dari itu mengembangkan model yang efektif dan mudah dalam penerapannya, sesuai dengan kondisi dan kebutuhan nyata di lapangan.

Penelitian ini menggunakan model penelitian dan pengembangan yang dikembangkan terdiri dari 10 langkah atau siklus, dimana rangkaian langkah-langkah penelitian dan pengembangan dilakukan secara siklik, dan pada setiap langkah yang akan dilalui atau dilakukan selalu mengacu pada hasil langkah sebelumnya hingga pada akhirnya diperoleh suatu produk yang baru.

Namun demikian pada pengembangan Model Latihan gerak aktif kaki dengan teknik open kinetic chain exercise pada lansia nyeri sendi ini dikelompokkan menjadi 3 tahap yaitu penyederhanaan dari 10 langkah menjadi 3 langkah yaitu tahap 1) studi pendahuluan yang terdiri atas kajian pustaka dan studi lapangan; 2) Pengembangan draf model yang terdiri dari penyusunan draf awal, uji coba terbatas, dan uji coba lebih luas; dan tahap 3) Pengujian yang dilaksanakan dalam bentuk eksperimen.

Luaran yang diharapkan dari penelitian ini adalah didapatkan suatu produk pengembangan model Latihan Gerak Aktif Kaki Isotonik dengan teknik open 
kinetic chain exercise khusus bagi usia lanjut penderita Osteoartritis sebagai alternative cara menurunkan intensitas nyeri, kekakuan, dan aktivitas fungsional pada usia lanjut penderita Osteoartritis, sehingga dapat dijadikan salah satu terapi dan program intervensi pada usia lanjut penderita Osteoartritis.

Perubahan yang diamati pada penelitian ini adalah Intensitas nyeri lansia penderita osteoarthritis. Intensitas nyeri diukur menggunakan NRS untuk mengukur intensitas nyeri sebelum dan sesudah dilakukan latihan gerak aktif kaki dengan teknik open kinetic chain exercise sebanyak 12 kali latihan.

\section{Lokasi dan Waktu Penelitian}

Penelitian ini dilaksanakan pada bulan Februari-Desember 2016 di Panti Werdha Minaula Kendari di Wilayah Kerja Puskesmas Ranomeeto Kendari.

\section{Populasi dan Sampel}

Populasi dalam penelitian ini adalah seluruh usia lanjut yang mengalami nyeri sendi di Panti Werdha Minaula dan Posyandu Lansia di wilayah kerja Puskesmas Poasia Kendari yang berjumlah 63 orang. Sampel dalam penelitian ini adalah 60 orang. Yang akan dibagi menjadi 2 kelompok, yaitu 30 orang kelompok intervensi dan 30 orang kelompok kontrol.

\section{Pengumpulan Data}

Perubahan yang diamati pada penelitian ini adalah intensitas nyeri lansia penderita osteoarthritis. Intensitas nyeri diukur menggunakan instrument Numeric Rating Scale (NRS) untuk mengukur intensitas nyeri sebelum dan sesudah dilakukan latihan gerak aktif kaki dengan teknik open kinetic chain exercise sebanyak 12 kali latihan.

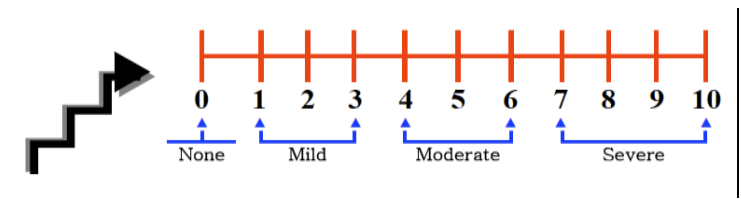

Kriteria obyektif:

$$
\begin{array}{ll}
0 & \text { : Tidak Nyeri } \\
1-3 & \text { : Nyeri Ringan } \\
4-6 & \text { : Nyeri Sedang } \\
7-10 & \text { : Nyeri Berat }
\end{array}
$$

\section{Pengolahan dan Analisis Data}

Analisis data bertujuan untuk melihat sebaran responden pada variabel penelitian sebelum dan setelah intervensi serta menguji variabel-variabel penelitian yaitu variabel independen (bebas) dan variabel dependen (terikat). Sebelum dilakukan analisis bivariat, untuk menentukan jenis uji bivariat yang digunakan maka perlu dilakukan uji homogenitas atau uji kesetaraan pada setiap variabel penelitian. Uji homogenitas dilakukan untuk membandingkan apakah karakteristik kelompok intervensi dan kelompok kontrol memiliki kesamaan varian (homogen atau tidak). Apabila pada uji homogenitas didapatkan nilai $\mathrm{p}>0,05$ maka variabel tersebut homogen atau ada kesetaraan antara kelompok intervensi dan kelompok kontrol. Uji homogenitas adalah merupakan salah satu prasyarat dilakukan analisis parametrik. Pada variabel yang homogen dapat langsung dianalisis menggunakan uji parametrik karena sudah memenuhi syarat untuk dilakukan uji parametrik, sedangkan pada variabel yang tidak homogen dilakukan transformasi data agar didapatkan data yang homogen. Namun jika setelah dilakukan transformasi data tetap menunjukan hasil yang tidak homogen maka analisisnya menggunakan uji non parametrik.

Uji statistik yang digunakan pada analisis bivariat adalah uji analisis komparatif (uji beda) yang akan dijabarkan berikut ini : (1) Uji beda dua mean sampel berpasangan (dependen). Uji ini digunakan untuk menguji kemaknaan perbedaan mean variabel penelitian antara sebelum dan setelah. Variabel yang akan dinilai menggunakan uji beda dua mean adalah variabel intensitas nyeri antara sebelum dan sesudah intervensi. Uji yang digunakan adalah paired t test. (2) Uji beda dua mean sampel tidak berpasangan (independen). Uji ini digunakan untuk menguji kemaknaan 
perbedaan mean variabel penelitian antara kelompok intervensi dan kelompok kontrol. Variabel yang dinilai menggunakan uji beda dua mean tidak berpasangan adalah intensitas nyeri antara kelompok intervensi dan kelompok kontrol. Uji yang digunakan adalah pooled t test.

\section{HASIL}

Karakteristik Responden

Tabel 1. Distribusi Karakteristik Responden di Panti Sosial Tresna Werdha Minaula Kendari

\begin{tabular}{|c|c|c|c|c|c|c|}
\hline \multirow{3}{*}{ Karakteristik } & \multicolumn{4}{|c|}{ Kelompok } & \multicolumn{2}{|c|}{ Total } \\
\hline & \multicolumn{2}{|c|}{ Intervensi } & \multicolumn{2}{|c|}{ Kontrol } & \multirow[b]{2}{*}{$\mathrm{n}$} & \multirow{2}{*}{$\%$} \\
\hline & $\mathrm{n}$ & $\%$ & $\mathrm{n}$ & $\%$ & & \\
\hline \multicolumn{7}{|l|}{ Jenis kelamin } \\
\hline Laki-laki & 11 & 36,7 & 11 & 36,7 & 22 & 36,7 \\
\hline Perempuan & 19 & 63,3 & 19 & 63,3 & 38 & 63,3 \\
\hline \multicolumn{7}{|l|}{ Umur } \\
\hline $60-74$ & 21 & 70,0 & 21 & 70,0 & 42 & 70,0 \\
\hline $75-90$ & 8 & 26,7 & 8 & 26,7 & 16 & 26,7 \\
\hline$>90$ & 1 & 3,3 & 1 & 3,3 & 2 & 3,3 \\
\hline \multicolumn{7}{|l|}{ Pendidikan } \\
\hline Tidak sekolah & 16 & 53,3 & 10 & 33,3 & 26 & 43,4 \\
\hline SD & 10 & 33,3 & 14 & 46,7 & 24 & 40,0 \\
\hline SMP & 3 & 10,0 & 5 & 16,7 & 8 & 13,3 \\
\hline SMA & 1 & 3,3 & 1 & 3,3 & 2 & 3,3 \\
\hline
\end{tabular}

Total jumlah responden yaitu 60 lansia mayoritas lansia dengan nyeri sendi berjenis kelamin perempuan, yaitu sebanyak 38 orang $(63,3 \%)$, kategori umur yang terbanyak adalah $60-74$ tahun yaitu 42 orang $(70,0 \%)$, kategori pendidikan terbanyak adalah tidak sekolah yaitu 26 orang $(43,4 \%)$.

Tabel 2. Distribusi Riwayat Keluarga dan Indeks Massa Tubuh Responden di Panti Sosial Tresna Werdha Minaula Kendari

\begin{tabular}{cccccccc}
\hline \multirow{2}{*}{ Karakteristik } & \multicolumn{4}{c}{ Kelompok } & \multicolumn{2}{c}{ Total } \\
\cline { 2 - 5 } & \multicolumn{2}{c}{ Intervensi } & \multirow{2}{c}{ Kontrol } & \multirow{2}{*}{$\%$} \\
\cline { 2 - 5 } & $\mathrm{n}$ & $\%$ & $\mathrm{n}$ & $\%$ & & \\
\hline Riwayat keluarga & 7 & 23,3 & 9 & 30,0 & 16 & 26,7 \\
Ya & 23 & 76,7 & 21 & 70,0 & 44 & 73,3 \\
Tidak & & & & & & \\
Indeks Massa Tubuh & 8 & 26,7 & 21 & 70,0 & 29 & 48,3 \\
$<18,5$ & 21 & 70,0 & 8 & 26,7 & 29 & 48,3 \\
$18,5-25$ & 1 & 3,3 & 1 & 3,3 & 2 & 3,4 \\
$>25$ & & & & & & & \\
\hline
\end{tabular}

Sumber data: hasil uji statistik data penelitian

Mayoritas lansia dengan nyeri sendi tidak memiliki riwayat keluarga penderita penyakit nyeri sendi yaitu 44 orang $(73,3 \%)$, dan kategori IMT yang terbanyak adalah dalam kategori kurus dan normal yaitu masing-masing sebanyak 29 orang $(48,3 \%)$.

\section{Gambaran Intensitas Nyeri Lansia \\ Penderita Nyeri Sendi Sebelum dan Sesudah Dilakukan Latihan Gerak Aktif Kaki dengan Teknik Open Kinetic Chain Exercise pada Kelompok Intervensi}

Tabel 3. Distribusi Intensitas Nyeri Kelompok Intervensi di PSTW Minaula Kendari, November

\begin{tabular}{cccccccc} 
& \multicolumn{4}{c}{$2016(\mathbf{n}=\mathbf{3 0})$} \\
\hline \multirow{2}{*}{$\begin{array}{c}\text { Intensitas } \\
\text { Nyeri }\end{array}$} & \multicolumn{4}{c}{ Frekuensi } & \multicolumn{2}{c}{ Mean $(\mathrm{SD})$} \\
\cline { 2 - 5 } & $\mathrm{n}$ & $\%$ & $\mathrm{n}$ & $\%$ & & \multirow{2}{c}{ Pre } & Post \\
\hline Tidak nyeri & 0 & 0 & 20 & 66,7 & 5,80 & 0,97
\end{tabular}




\begin{tabular}{lcccccc} 
Ringan & 3 & 10,0 & 9 & 30,0 & $(1,424)$ & $(1,650)$ \\
Sedang & 12 & 40,0 & 0 & 0 & \\
Berat & 15 & 50,0 & 1 & 3,3 \\
\hline \multicolumn{5}{c}{ Sumber data: } \\
hasil uji statistik data penelitian
\end{tabular}

Hasil analisis distribusi lansia dengan nyeri sendi berdasarkan intensitas nyeri pada kelompok intervensi diperoleh data bahwa pada saat sebelum dilakukan intervensi latihan gerak aktif kaki dengan teknik open kinetik chain exercise rata-rata intensitas nyeri adalah 5,80 dengan SD 1,424 dengan kategori nyeri yang terbesar adalah pada kategori nyeri berat yaitu 15 orang $(50 \%)$, sedangkan setelah intervensi rata-rata intesitas nyeri adalah 0,97 dengan SD 1,650 dengan kategori intensitas nyeri yang terbanyak adalah tidak nyeri yaitu 20 orang $(66,7 \%)$.

Tabel 4. Distribusi Intensitas Nyeri Kelompok Kontrol di PSTW Minaula Kendari, November

\begin{tabular}{lcccccc}
\multicolumn{4}{c}{$\mathbf{2 0 1 6}(\mathbf{n}=\mathbf{3 0})$} \\
\hline \multirow{2}{*}{$\begin{array}{l}\text { Intensitas } \\
\text { Nyeri }\end{array}$} & \multicolumn{4}{c}{ Frekuensi } & \multicolumn{2}{c}{ Mean $(\mathrm{SD})$} \\
\cline { 2 - 5 } & $\mathrm{n}$ & $\%$ & $\mathrm{n}$ & $\%$ & \multirow{2}{*}{ Pre } & Post \\
\hline Tidak nyeri & 0 & 0 & 0 & 0 & & \\
Ringan & 8 & 26,7 & 7 & 23,3 & 5,50 & 5,37 \\
Sedang & 5 & 16,6 & 10 & 33,3 & $(1,996)$ & $(1,847)$ \\
Berat & 17 & 56,7 & 13 & 43,3 & & \\
\hline
\end{tabular}

Sumber data: hasil uji statistik data penelitian

Hasil analisis distribusi lansia dengan nyeri sendi berdasarkan intensitas nyeri pada kelompok kontrol diperoleh data bahwa pada saat sebelum dilakukan intervensi latihan gerak aktif kaki dengan teknik open kinetik chain exercise rata-rata intensitas nyeri adalah 5,50 dengan SD 1,996 dengan kategori nyeri yang terbesar adalah pada kategori nyeri berat yaitu 17 orang $(56,7 \%)$, sedangkan setelah intervensi rata-rata intesitas nyeri adalah 5,37 dengan SD 1,847 dengan kategori intensitas nyeri yang terbanyak adalah nyeri berat yaitu 13 orang $(43,3 \%)$.

\section{Analisis Perbedaan Intensitas Nyeri Sebelum dan Sesudah Intervensi pada Kelompok Intervensi dan Kontrol}

Tabel 5. Analisis Perbedaan Intensitas Nyeri Sebelum dan Sesudah Intervensi pada Kelompok Intervensi dan Kontrol

\begin{tabular}{cccccc}
\hline Variabel & $\mathrm{n}$ & Mean & Beda Mean & SD & $p$-value \\
\hline Kelompok intervensi & & & & & \\
Sebelum & 30 & 5,80 & 4,83 & 1,424 & 0,000 \\
Sesudah & 30 & 0,97 & & 1,650 & \\
Kelompok kontrol & & & & & \\
Sebelum & 30 & 5,50 & 0,13 & 1,996 & 0,588 \\
Sesudah & 30 & 5,37 & & 1,847 & \\
\hline
\end{tabular}

Sumber data: hasil uji statistik data penelitian

Rata-rata intensitas nyeri lansia penderita nyeri sendi pada kelompok intervensi sebelum dilakukan intervensi latihan gerak aktif kaki dengan teknik open kinetik chain exercise adalah 5,80 dengan standar deviasi 1,424. Sesudah dilakukan intervensi didapatkan rata-rata intensitas nyeri lansia penderita nyeri sendi adalah 0,97 dengan standar deviasi 1,650. Hasil analisis didapatkan bahwa ada perbedaan intensitas nyeri lansia penderita nyeri sendi antara sebelum dan sesudah dilakukan intervensi latihan gerak aktif kaki dengan teknik open kinetik chain exercise yaitu ratarata intensitas nyeri lansia penderita nyeri sendi sesudah dilakukan intervensi lebih rendah daripada sebelum dilakukan intervensi pada kelompok intervensi $(\mathrm{p}=$ $0,000 ; \alpha=0,05)$. 
Rata-rata intensitas nyeri lansia penderita nyeri sendi pada kelompok kontrol sebelum dilakukan intervensi latihan gerak aktif kaki dengan teknik open kinetik chain exercise adalah 5,50 dengan standar deviasi 1,996. Sesudah dilakukan intervensi didapatkan rata-rata intensitas nyeri lansia penderita nyeri sendi adalah 5,37 dengan standar deviasi 1,847. Hasil analisis didapatkan bahwa tidak ada perbedaan

Tabel 6. Analisis Perbedaan Intersintas Nyeri Sesudah Intervensi pada Kedua Kelompok

\begin{tabular}{lcccc}
\hline \multicolumn{1}{c}{ Variabel } & $\mathrm{n}$ & Mean & SD & $p$-value \\
\hline Kelompok intervensi & 30 & 0,97 & 1,650 & 0,000 \\
Kelompok kontrol & 30 & 5,37 & 1,847 & \\
\hline
\end{tabular}

Sumber data: hasil uji statistik data penelitian

Ada perbedaan intensitas nyeri antara kelompok intervensi dan kelompok kontrol sesudah dilakukan intervensi latihan gerak aktif kaki dengan teknik open kinetik chain exercise $(\mathrm{p}=0,000 ; \alpha=0,05)$.

\section{Analisis Multivariat Pengaruh Latihan Gerak Aktif kaki terhadap Intensitas Nyeri setelah Variabel Perancu Dikontrol}

Analisis multivariat dilakukan untuk mengidentifikasi variable independen mana yang paling besar pengaruhnya terhadp variabel dependen, apakah variabel independen berhubungan dengan variabel dependen dipengaruhi oleh variael lain atau tidak, atau untuk mengidentifikasi bentuk hubungan beberapa variabel independen dengan variabel dependen apakah berhubungan langsung atau pengaruh tidak langsung.

Untuk mengetahui pengaruh latihan gerak aktif kaki dengan teknik open kinetic chain terhadap intensitas nyeri setelah dikontrol variabel perancu maka dilakukan analisis multivariate. Uji statistik yang digunakan adalah uji regresi linear. Tahapan analisis multivariat meliputi pemilihan variabel kandidat multivariat, pembuatan model dan uji asumsi. Berikut ini akan dilaporkan hasil analisis multivariat dengan uji regresi linear ganda secara bertahap.

Langkah pertama yang dilakukan adalah melakukan pemilihan variabel intensitas nyeri lansia penderita nyeri sendi antara sebelum dan sesudah dilakukan intervensi latihan gerak aktif kaki dengan teknik open kinetik chain exercise $(\mathrm{p}=$ $0,588 ; \alpha=0,05)$.

\section{Perbedaan Intensitas Nyeri Sesudah Intervensi antara Kelompok Intervensi dan Kelompok Kontrol}

kandidat multivariat dengan menganalisis bivariat antara variabel confounding dengan variabel dependen (bila $p$ value $<0,05$ maka masuk model multivariat). Dalam penelitian ini, terdapat satu variabel yang diduga dapat mempengaruhi intervensi latihan gerak aktif kaki dengan teknik open kinetic chain terhadap intensitas nyeri lansia dengan nyeri sendi yaitu riwayat (variabel confounding). Hasil analisis bivariat antara variabel confounding dengan variabel dependen dapat dilihat pada tabel berikut ini :

Tabel 7. Hasil Analisis Penentuan Kandidat Multivariat

\begin{tabular}{lcc}
\hline Variabel & Nilai F & $p$-value \\
\hline Umur & 1,667 & 0,489 \\
Jenis kelamin & 0,105 & 0,362 \\
Riwayat & 0,116 & 0,008 \\
IMT & 0,248 & 0,354 \\
Latihan gerak aktif kaki & 14,186 & 0,076 \\
\hline \multicolumn{2}{l}{ Sumber data: hasil uji statistik data } & penelian
\end{tabular}

Berdasarkan hasil di atas, dapat diketahui bahwa diantara 5 variabel, ada dua variabel yang dapat masuk dalam model multivariat yaitu variabel riwayat dan latihan gerak aktif kaki. Hal ini disebabkan karena kedua variabel ini mempunyai nilai $p$ value $<0,25$. Dengan demikian, dapat disimpulkan bahwa variabel riwayat dan latihan gerak aktif kaki dapat mempengaruhi intensitas nyeri lansia dengan nyeri sendi.

Langkah kedua yang dilakukan adalah menentukan model untuk menentukan determinan intensitas nyeri lansia dengan 
nyeri sendi dengan cara melakukan uji regresi linier pada variabel yang memenuhi syarat uji multivariat. Tabel 7 menunjukan hasil uji regresi linier pada variabel yang memenuhi syarat uji multivariat.

Tabel 8. Hasil Uji Regresi Linear terhadap Variabel yang dapat Mempengaruhi Intervensi Latihan

\begin{tabular}{lcccc}
\hline Variabel & $\mathrm{B}$ & $\begin{array}{c}p- \\
\text { value }\end{array}$ & $\mathrm{R}$ & $\begin{array}{c}R \text { - } \\
\text { square }\end{array}$ \\
\hline Riwayat & 1,430 & 0,007 & 0,779 & 0,639 \\
Latihan & $-2,983$ & 0,000 & & \\
\hline
\end{tabular}

Sumber data: hasil uji statistik data penelitian

Dari hasil uji diatas didapatkan bahwa tidak ada variabel perancu memiliki nilai $p$ value $>0,05$. Langkah selanjutnya adalah pembuatan model terakhir setelah mengeluarkan variabel perancu dengan nilai $\mathrm{p}$ value $>0,05$.

Tabel 9. Hasil Analisis Multivariat Regresi Linier

\begin{tabular}{cclc}
\hline $\mathrm{r}$ & $\begin{array}{c}R- \\
\text { square }\end{array}$ & Persamaan Garis & $\begin{array}{c}p- \\
\text { value }\end{array}$ \\
\hline 0,779 & 0,636 & intensitas nyeri $=$ & 0,000 \\
& & 3,194 \\
& & \\
& & \\
& $-2,430$ riwayat & \\
& & \\
\hline
\end{tabular}

Sumber data: hasil uji statistik data penelitian

Berdasarkan hasil tersebut dapat dilihat bahwa hubungan intervensi latihan gerak aktif kaki dengan teknik open kinetic chain dan riwayat dengan intensitas nyeri menunjukan hubungan yang kuat $(\mathrm{r}=$ 0,779). Dari hasil di atas juga diperoleh bahwa latihan gerak aktif kaki dengan teknik open kinetic chain dan riwayat menentukan intensitas nyeri sebesar 63,9\%, sisanya ditentukan oleh faktor lain yang tidak diteliti dalam penelitian ini.

Selanjutnya untuk mengidentifikasi faktor dominan yang mempengaruhi intensitas nyeri lansia dengan nyeri sendi dapat dilihat pada tabel berikut ini :

Tabel 10. Hasil Analisis Faktor Dominan yang Mempengaruhi Intensitas Nyeri

\begin{tabular}{lrr}
\hline Variabel & B & $p$-value \\
\hline Umur & 0,324 & 0,547 \\
Jenis kelamin & 0,698 & 0,165 \\
Riwayat & 1,337 & 0,019 \\
\hline
\end{tabular}

\begin{tabular}{lcc}
\hline IMT & 0,361 & 0,789 \\
Latihan gerak kaki & $-2,966$ & 0,000 \\
\hline
\end{tabular}

Sumber data: hasil uji statistik data penelitian

Paling dominan mempengaruhi intensitas nyeri lansia dengan nyeri sendi adalah variabel yang memiliki nilai coef. $\mathrm{B}$ yang paling tinggi. Dari tabel di atas diketahui bahwa variabel dominan yang mempengaruhi intensitas nyeri penderita nyeri sendi adalah latihan gerak aktif kaki dengan teknik open kinetic chain dengan nilai coef B yaitu 2,966.

Pada kelompok intervensi, terjadi penurunan intensitas nyeri lansia dengan nyeri sendi sesudah diberikan intervensi latihan gerak aktif kaki dengan teknik open kinetik chain sebesar 4,83. Untuk membuktikan bahwa intervensi latihan gerak aktif kaki dengan teknik open kinetik chain efektif dalam menurunkan intensitas nyeri lansia dengan nyeri sendi adalah dengan melakukan uji statistik dengan paired $t$ test, dimana hasil uji menunjukan bahwa ada pengaruh latihan gerak aktif kaki dengan teknik open kinetik chain terhadap penurunan intensitas nyeri lansia dengan nyeri sendi di PSTW Minaula Kendari $(\mathrm{p}=0,000 ; \alpha=0,05)$. Dengan demikian maka latihan gerak aktif kaki dengan teknik open kinetik chain efektif dalam menurunkan intensitas nyeri lansia dengan nyeri sendi.

\section{PEMBAHASAN}

Nyeri merupakan gejala utama pada pasien Rheumatoid Arthritis dan Osteoarthritis yang sering menyebabkan pasien membatasi aktivitasnya. Latihan penguatan dapat mengurangi keluhan nyeri. Pada tahap awal digunakan latihan penguatan otot isometrik karena gerak sendi yang terbatas sehingga tidak menimbulkan nyeri. Selain itu sebelum melakukan latihan harus dilakukan latihan pemanasan muskuloskletal dan kardiovaskular serta latihan fleksibilitas. Latihan dilakukan sebatas gerakan bebas nyeri serta harus menghindari postur dan gerakan yang meningkatkan nyeri dan menimbulkan edema. Pasien juga diajari untuk memonitor 
sendiri latihannya untuk menghindari nyeri dan delayed onset muscle soreness.

Latihan gerak aktif adalah menggerakkan setiap persendian dengan maksimal dan bebas tanpa menyebabkan rasa nyeri (Elyas, 2002). Latihan gerak aktif adalah latihan yang menggerakkan persendian seoptimal dan seluas mungkin sesuai kemampuan seseorang yang tidak menimbulkan rasa nyeri pada sendi yang digerakkan. Latihan gerak aktif pada penelitian ini merupakan gerakan-gerakan yang banyak dilakukan pada kegiatan seharihari. Adanya pergerakan pada persendian akan menyebabkan terjadinya peningkatan aliran darah pada kapsul sendi (Indri s., 2015).

Latihan gerak aktif dalam penelitian ini adalah menggunakan latihan dengan tekhnik open kinetic chain, konsep awal dari kinetic chain berasal dari bidang mekanik yang kemudian dipublikasikan kembali oleh Reuleux pada tahun 1875, didalamnya mempelajari tentang bermacam-macam rangkaian gerakan, rangkaian gerakan tersebut dihasilkan dari beberapa segmen yang saling berhubungan melalui suatu persendian dimana hal ini akan menjadi suatu sistem untuk memungkinkan terjadinya pergerakan satu segmen pada satu sendi atau beberapa segmen yang diikuti oleh sendi lainnya (Kisner C., Cosby L.A, 2007).

Pada open kinetic chain segmen distal terjadi pergerakan atau tidak terfiksasi (insersio bergerak terhadap origo) biasanya pada open kinetic chain pergerakan hanya terjadi pada satu sendi (single joint) dan tanpa disertai pergerakan pada segmen proksimalnya, contoh pergerakan pada open kinetic chain antara lain ayunan kaki saat berjalan (swing phase), menendang atau melempar bola, ayunan tangan saat berjalan (Fehr G.L., Cacho E.W.A., Miranda J.B,. 2006).

Kachanathu dkk (2013) pada artikelnya yang berjudul Open or Closed Kinetic Chain Exercise After Anterior
Cruciatum Ligament Reconstruction menyatakan bahwa perbedaan antara open dan closed kinetic chain exercise tidak pada pergerakan kinematik tetapi lebih pada gaya beban yang ditransmisikan ke knee joint (single joint) sedangkan pada closed kinetic chain beban ditransmisikan ke sendi ankle, knee, dan hip joint (multiple joint).

Latihan penguatan dimulai dengan latihan penguatan isometrik (brief isometric exercise) karena latihan ini tidak melibatkan gerakan sendi dan tidak memperberat gejala OA lutut. Sendi lutut diposisikan pada posisi yang nyaman (biasanya posisi ekstensi) dan kemudian otot quadrisep dikontraksikan maksimal selama minimal 6 detik, minimal dilakukan 2 kali sehari. Sambil melakukan kontraksi otot pasien diminta untuk menghitung dengan suara keras untuk menghindari manuver Valsava. Penggunaan elastic belt atau rubber loop yang terbuat dari tire inner tube ( ban dalam) merupakan cara praktis untuk mendapat feedback proprioseptif saat otot berkontraksi isometrik melawan tahanan. Kontraksi isometrik harus ditahan minimal 6 detik untuk memungkinkan tercapainya puncak tegangan otot dan perubahan metabolik di otot, dan tidak boleh lebih dari 10 detik karena akan menyebabkan otot cepat kelelahan/fatique.

Latihan quadricep setting adalah contoh latihan penguatan isometrik otot quadrisep dengan fokus pada kontraksi vastus medialis obliq. Latihan dilakukan dengan pasien posisi supine atau duduk dan lutut posisi ekstensi dan pergelangan kaki dorsifleksi. Pasien diberi perintah "tekan lutut anda ke bawah, dan kencangkan otot paha”. Kontraksi ditahan selama 6-10 detik, istirahat beberapa detik, dan kemudian kontraksi lagi. Latihan dilakukan 8-12 kali repetisi, diulang beberapa kali sehari. Jika pasien merasa kurang nyaman, bisa ditambahkan gulungan handuk di bawah lutut.

Untuk menghindari cedera pada otot, berikan tahanan secara bertahap, serta turunan kontraksi otot secara bertahap pula. 
Hal ini membantu peningkatan tegangan/tension otot secara bertahap, menjamin kontraksi otot yang bebas nyeri, dan menghindari resiko gerakan sendi yang tidak terkontrol.

Dalam penelitian ini ditemukan bahwa mayoritas responden $(76,7 \%)$ melakukan teknik relaksasi sesuai pedoman dan jadwal yaitu satu kali sehari pada pagi hari selama 12 kali, sedangkan sisanya $23,3 \%$ hanya melakukan latihan gerak aktif kaki dengan teknik open kinetik chain sebanyak delapan kali.

Pelaksanaan latihan gerak aktif kaki sesuai dengan pedoman dan jadwal maka akan memberikan efek yang lebih besar dan memberikan efek terapeutik yang lebih baik dalam menurunkan intensitas nyeri lansia dengan nyeri sendi. Hal ini terbukti dari hasil penelitian didapatkan bahwa pada lansia yang melakukan latihan gerak aktif kaki teratur atau sesuai pedoman $(n=23)$ yaitu sebanyak satu kali sehari selama 12 hari menunjukan penurunan intensitas nyeri sebesar 6,00, sedangkan pada lansia dengan nyeri sendi yang tidak melaksanakan latihan gerak aktif kaki dengan teknik open kinetik chain sesuai pedoman $(\mathrm{n}=7)$ hanya menunjukan penurunan intensitas nyeri sebesar 4,48 .

\section{KESIMPULAN DAN SARAN}

Kesimpulan dari penelitian ini adalah Ada pengaruh latihan gerak aktif kaki dengan teknik open kinetik chain terhadap intensitas nyeri lansia dengan nyeri sendi di Panti Sosial Trena Werdha Minaula Kendari, Hal ini ditunjukan dengan data pada saat sesudah intervensi rata-rata intensitas nyeri pada kelompok intervensi lebih rendah daripada kelompok kontrol (Intervensi $=0,97$; Kontrol $=5,37$ ). Dengan demikian maka terjadi penurunan intensitas nyeri lansia dengan nyeri sendi sesudah diberikan intervensi latihan gerak aktif kaki dengan teknik open kinetik chain sebesar 4,83. Selanjutnya faktor dominan yang paling mempengaruhi intensitas nyeri lansia dengan nyeri sendi di panti Sosial Tresna
Werdha Minaula Kendari adalah latihan gerak aktif kaki dengan teknik open kinetik chain setelah mengontrol variabel riwayat.

Saran yang bisa direkomendasikan dari hasil penelitian ini adalah agar Latihan gerak aktif kaki dengan teknik open kinetik chain menjadi salah satu kompetensi yang harus dimiliki perawat dan dijadikan sebagai intervensi dalam asuhan keperawatan terkait penatalaksanaan nyeri sendi nonfarmakologis, serta Perlu dibuat buku panduan perawatan nyeri sendi di Panti dan di rumah dengan latihan gerak aktif kaki dengan teknik open kinetik chain sebagai salah satu cara perawatan yang dianjurkan, serta diperlukan simulasi pelaksanaan latihan gerak aktif kaki dengan teknik open kinetik chain oleh kader kesehatan atau petugas kesehatan kepada masyarakat.

\section{DAFTAR PUSTAKA}

Depkes, RI. 2010. Penerapan Proses Keperawatan pada Klien dengan Gangguan Sistem Maskuloskeletal, Jakarta : Pusdiknakes.

Elyas E. 2002. Pendekatan Terapi Fisik pada Osteoarthritis. Pertemuan Ilmiah Tahunan PERDOSRI 2002. Bidang Pendidikan dan Latihan Pengurus Besar PERDOSRI. Jakarta.

Fehr G.L; Junior A.C; Cacho E.W.A; Miranda J.B. 2006. Effectiveness of The Open and Closed Kinetik Chain exercises in The Treatment of the Patellofemoral Pain Syndrome. Journal Rev Bras Med Esporte - Vol 12 No. 2 - Mar/Abr, 2006 diakses 1 Juni 2016

Herry Isbagio, Bambang SH . 2009. Masalah dan Penanganan Osteoarthritis Sendi lutut. Cermin Dunia Kedokteran.

Indri S. 2015. Latihan closed kinetic chain lebih baik daripada open kinetic chain untuk meningkatkan kemampuan fungsional pada osteoarthritis lutut setelah pemberian micro wave diathermy (MWD) dan transcutaneus electrical nerve stimulation (TENS). 2015.http://ojs.unud.ac.id/index.php/s port/article/diakses 3 Juni 2015 
Kachanathu S.J; Kaur H; Natho ; and Available:http://www.depkes.go.id/di Nuhmani S. 2013. The Effect of Open and Closed Kinematics Chan Exercises in The Management of Meniscal injuries. Journal of Scientific and innovative research 2013; 2 (5): 927-931 diakses 1 Juni 2016.

Kisner C, Cosby LA. 2007. Therapeutic Exercise Foundation and Technique. $5^{\text {th }}$ ed. Phildelphia : F.A. Davis Company.

Kemenkes RI. 2013. Gambaran Kesehatan akses 3 Juni 2015

Nugroho H.B. 2015. Pengaruh Open Kinetic chain Dan Closed Kinetic Chain Terhadap Peningkatan Aktivitas Fungsional Pada Osteoarthritis Knee Setelah pemberian Transkutaneus Electrical Nerves Stimulation Dan Infra Red radiation. Skripsi. Universitas Muhammadiyah Surakarta. Diakses 1 Juni 2016. Lanjut Usia di Indonesia. [internet].

\section{INFORMASI TAMBAHAN}

\section{Lisensi}

Hakcipta ( $\odot$ Asminarsih Zainal Prio dkk. Artikel akses terbuka ini dapat disebarkan seluas-luasnya sesuai aturan Creative Commons Attribution-ShareAlike 4.0 International License dengan catatan tetap menyebutkan penulis dan penerbit sebagaimana mestinya.

\section{Catatan Penerbit}

Polekkes Kemenkes Kendari menyatakan tetap netral sehubungan dengan klaim dari perspektif atau buah pikiran yang diterbitkan dan dari afiliasi institusional manapun.

\section{DOI}

https://doi.org/10.36990/hijp.v9i1.76 